\title{
Instrumen Asesmen Berpikir Kritis Dalam Pembelajaran Membaca Teks Eksposisi untuk Siswa Kelas VIII SMP
}

\author{
Adi Syahputra Manurung ${ }^{1}$, Muakibatul Hasanah ${ }^{1}$, Wahyudi Siswanto ${ }^{1}$ \\ ${ }^{1}$ Pendidikan Bahasa Indonesia-Universitas Negeri Malang
}

\section{INFO ARTIKEL}

\section{Riwayat Artikel:}

Diterima: $17-12-2019$

Disetujui: $15-06-2020$

\section{Kata kunci: \\ assessment instruments; critical thingking; read exposition text instrumen asesmen; berpikir kritis; membaca teks eksposisi}

\author{
Alamat Korespondensi: \\ Adi Syahputra Manurung \\ Pendidikan Bahasa Indonesia \\ Universitas Negeri Malang \\ Jalan Semarang 5 Malang \\ E-mail: adi.putra.manurung@gmail.com
}

\begin{abstract}
ABSTRAK
Abstract: Critical thinking skills are one of the skills that must be possessed in the $21^{\text {st }}$ century. Tools to measure students' thinking competencies can use assessment instruments. Based on the needs analysis, information was obtained that the use of assessment instruments for the junior high school level was still limited. The purpose of this study (1) to develop critical thinking assessment instruments in learning to read exposition texts along with usage guidelines and (2) test the level of validity, reliability, and practicality of the product. The model used is the development of O'Malley and Pierce. The results of product validation and testing show that the product developed is feasible and can be implemented. The data was obtained from the assessment and learning validator, and product tests on students
\end{abstract}

\begin{abstract}
Abstrak: Keterampilan berpikir kritis merupakan salah satu keterampilan yang harus dimiliki pada abad 21. Alat untuk mengukur kompetensi berpikir siswa dapat menggunakan instrumen asesmen. Berdasarkan analisis kebutuhan diperoleh informasi masih terbatasnya penggunaan instrumen asesmen untuk tingkat SMP. Tujuan penelitian ini (1) mengembangkan instrumen asesmen berpikir kritis dalam pembelajaran membaca teks eksposisi beserta panduan penggunaan dan (2) menguji tingkat validitas, reliabilitas, dan kepraktisan produk. Model yang digunakan adalah model pengembangan O'Malley dan Pierce. Hasil validasi dan uji produk menunjukkan bahwa produk yang dikembangkan tergolong layak dan dapat diimplementasikan. Data tersebut diperoleh dari validator asesmen dan pembelajaran, serta uji produk pada siswa.
\end{abstract}

Peranan asesmen atau penilaian merupakan hal yang krusial dilakukan dalam proses, maupun pada akhir pembelajaran di sekolah (Tosuncuoglu, 2018a). Seringkali asesmen juga diartikan sebagai suplemen atau penunjang pembelajaran (Wardani, 2017). Asesmen merupakan proses pengumpulan informasi dari peserta didik mengenai apa yang diketahui atau tidaknya setelah memeroleh materi pelajaran di sekolah. Informasi tersebut digunakan sebagai dasar dalam membuat suatu keputusan mengenai mutu atau kualitas pembelajaran (Wahyuni \& Ibrahim, 2014). Sejalan dengan itu, Xu \& Liu (2009) menyatakan bahwa yang krusial harus dimiliki oleh guru dalam proses pembelajaran terdiri atas tiga, yaitu (1) pengetahuan tentang asesmen, (2) praktik penilaian, dan (3) pengembangan profesional dalam penilaian. Dengan melakukan penilaian, seorang guru akan mengetahui kesulitan yang dihadapi oleh peserta didik, serta akan mencari solusi untuk mengatasi kesulitan belajar siswa tersebut (Zainal, Priyatni, \& Widiati, 2018). Hasil penilaian tersebut dapat menjadi acuan dan bahan evaluasi dalam menciptakan kemajuan belajar peserta didik

Asesmen memiliki fungsi selain untuk mengukur kemampuan siswa dalam belajar, juga sebagai refleksi guru mengenai metode, model, dan strategi yang telah dilakukan dalam menyajikan materi pembelajaran kepada siswa. Hal tersebut menandakan kalau asesmen tidak terlepas dari pembelajaran, pun sebaliknya (Wijayanti \& Mundilarto, 2015). Senada dengan itu, Sudjana (2017) berpendapat bahwa asesmen tidak hanya serta-merta ingin mencapai tujuan instruksional saja, melainkan juga sebagai umpan balik dalam upaya meningkatkan kegiatan belajar-mengajar. Menurut (Chusnia, Sa'dijah, \& Harsiati, 2017) asesmen juga berfungsi untuk mendiagnosa gambaran hasil belajar peserta didik dari segi kelebihan maupun kekurangannya pada aspek kognitif, afektif, maupun psikomotorik.

Asesmen yang dirancang tidak terlepas dari tujuan yang hendak dicapai. Tujuan asesmen yang dilakukan oleh guru menurut (Black \& Wiliam, 1998) setidaknya terdiri atas dua, yaitu (1) untuk mengembangkan kapasitas siswa dalam mengenali dan memahami materi pembelajaran dan (2) untuk memeroleh stimulus informasi mengenai kompetensi peserta didik untuk mengarahkan kegiatan selanjutnya. Menurut (Kasmadi \& Harsiati, 2016) bahwa rancangan instrumen asesmen seyogiyanya 
bertujuan untuk membelajarkan peserta didik mengenai makna harafiah dari suatu teks berdasarkan fungsi sosial dan tujuannya. Asesmen dilakukan untuk memonitoring interaksi pada pembelajaran yang telah dilakukan oleh guru di dalam kelas (Yeo \& Boman, 2019)

Instrumen asesmen adalah sebuah alat atau perangkat yang digunakan untuk merepresentasikan kompetensi peserta didik. Upaya yang dapat dilakukan untuk mencapai pembelajaran yang berkualitas salah satunya adalah dengan merancang sistem penilaian yang baik dan tepat sasaran (Ekawatiningsih, 2015). Instrumen asesmen berkedudukan sangat strategis dalam pengambilan keputusan terkait hasil belajar peserta didik (Dharmawati \& Mahanal, 2016). Kualitas instrumen asesmen berpengaruh langsung pada keakuratan hasil pengukuran tentang pencapaian kompetensi peserta didik. Pandangan (Mueller, 2015) menegaskan bahwa metode/model asesmen yang digunakan harus benar-benar dapat menguraikan segala aspek yang diketahui dan dilakukan siswa. Penilaian hasil belajar diharapkan tidak hanya sebagai ajang untuk mengukur sejauh mana kemampuan siswa, melainkan juga dapat meningkatkan keterampilan siswa dalam berpikir kritis. Dalam Permendikbud 2016 tentang standar isi dipaparkan bahwa guru harus mampu mengembangkan keterampilan yang kompetitif yang berfokus pada pengembangan berpikir tingkat tinggi (higher order thingking skills) termasuk didalamnya keterampilan berpkir kritis. Berkaitan dengan hal tersebut, guru seyogyanya menciptakan peluang bagi peserta didik dalam meningkatkan produktivitas dan kompetensi berpikir kritis (Paxhia, 2014).

Berpikir kritis merupakan cara kerja otak untuk menemukan pengalaman nyata (Maltepe, 2016). Kekritisan ialah salah satu aspek dari cara berpikir seseorang (Gotoh, 2016). Keterampilan berpikir kritis dapat membantu kita dalam memecahkan persoalan, melatih membuat keputusan, dan mencapai tujuan yang diharapkan (Tosuncuoglu, 2018b) Kompetensi berpikir kritis adalah kemampuan berpikir reflektif dan masuk akal yang terfokus pada usaha mengambil keputusan tentang apa yang harus percaya atau harus dilakukan (Abidin, 2016). Bertemali dengan itu, (Batur, Başar, \& Nilüfer Süzen, 2019) menyatakan bahwa berpikir kritis adalah proses metakognitif yang melibatkan kemampuan dalam mengajukan pertanyaan, pencarian solusi dari pertanyaan dengan memahami dasar/konsep pertanyaan, bersikap objektif, berfokus pada logika, dan berpikir reflektif terhadap informasi. Berpikir kritis juga dapat diartikan sebagai disiplin ilmu atau seni berpikir yang dapat digunakan untuk memastikan bahwa seorang individu menggunakan pemikiran terbaik dalam melakukan sesuatu (Paul \& Elder, 2002).

Kecakapan berpikir kritis merupakan keterampilan yang harus dimiliki oleh peserta didik sedini mungkin untuk mempersiapkan generasi yang mampu menghadapi tantangan global. Hasil survei global, seperti Programme International Students Assessment (PISA) menunjukkan bahwa pelajar Indonesia berada dalam tingkat literasi yang rendah. Padahal disisi lain kemampuan membaca merupakan hal yang penting untuk dimiliki setiap peserta didik. Survey yang dilakukan World's Most Literate Nation thn. 2016 menunjukkan kalau minat baca orang Indonesia berada pada posisi urutan kedua terbawah dari 62 negara yang diuji (Nabilah, Damaianti, \& Agustin, 2018). Oleh sebab itu, keterampilan berpikir kritis dalam pembelajaran membaca perlu dilakukan untuk menyiapkan kompetensi dan meningkatkan kualitas peserta didik yang sesuai perkembangan abad 21 (Cohen, 2009).

Pada dasarnya keterampilan berpikir kritis bukanlah suatu hal yang dibawa sejak lahir melainkan harus dilatihkan lewat interaksi dan belajar. Sesuai kurikulum di sekolah saat ini siswa diajarkan berbagai macam teks yang dapat berguna dalam kehidupannya. Salah stu teks yang dapat digunakan dalam mengembangkan kompetensi siswa berpikir kritis, yakni teks eksposisi. Teks eksposisi menyajikan sejumlah fakta informasi yang aktual dan berguna untuk wawasan peserta didik (Sari, Dawud, \& Andajani, 2019). Oleh karena itu, Zhang \& Kim (2018) berpandangan bahwa penilaian rasional atau mengingat informasi, serta untuk mendapatkan informasi yang berguna baginya, peserta didik harus membaca dengan menggunakan kompetensi menginterpretasi, menganalisis, mengevaluasi, menginferensi, mengeksplanasi, dan meregulasi diri (Facione, 1990).

Studi pendahuluan telah dilakukan di empat SMP Negeri yang ada di kota Malang. Hal tersebut dilakukan untuk mengetahui alat asesmen yang digunakan oleh guru dalam melakukan penilaian pada proses belajar mengajar maupun pada kegiatan akhir pembelajaran. Langkah yang dilakukan peneliti pada tahap ini adalah dengan melakukan wawancara secara langsung kepada guru, menyebarkan angket, dan melakukan observasi terhadap perangkat pembelajaran yang digunakan oleh guru. Temuan yang diperoleh pada tahap studi pendahuluan/analisis kebutuhan bahwa guru telah melakukan penilaian. Namun, guru-guru masih belum mengembangkan instrumen asesmen secara mandiri, dan cenderung menggunakan instrumen yang konvensional (sudah ada). Selain itu, instrumen asesmen biasanya digunakan berdasarkan buku pegangan guru yang dibagikan pemerintah, dan dilakukan hanya pada saat ulangan maupun penilaian akhir semester.

Berdasarkan paparan di atas, tujuan umum dilakukannya penelitian dan pengembangan ini adalah untuk menghasilkan sebuah produk asesmen untuk diimplementasikan kepada siswa kelas VIII SMP. Secara khusus yang menjadi tujuan penelitian dan pengembangan ini, yaitu (1) menghasilkan perangkat berupa buku instrumen asesmen berpikir kritis dalam pembelajaran membaca teks eksposisi yang memenuhi persyaratan kelayakan dari segi validitas, reliabilitas, kepraktisan, dan kemenarikan, (2) menghasilkan perangkat berupa buku panduan instrumen asesmen yang layak berdasarkan aspek validitas dan kepraktisan, dan (3) menguji dan mendeskripsikan hasil uji kedua produk berdasarkan kriteria validitas, reliabilitas, kepraktisan, dan kemenarikan produk. 


\section{METODE}

Model yang digunakan dalam penelitian dan pengembangan ini adalah model asesmen pembelajaran bahasa (O'Malley \& Pierce, 1996). Model pengenbangan instrumen asesmen O’Malley dan Pierce terdiri atas delapan tahap pelaksanaan, yaitu (1) membangun anggota tim asesmen, (2) menentukan tujuan asesmen, (3) menyusun spesifikasi produk asesmen, (4) memimpin pengembangan secara profesional pada asesmen, (5) mengkaji penelitian terdahulu mengenai asesmen, (6) mengadaptasi asesmen terdahulu dan mengembangkan asesmen yang baru, (7) melakukan uji coba asesmen yang dikembangkan, dan (8) meninjau ulang asesmen.

Pada penelitian dan pengembangan ini, peneliti melalui delapan tahapan model O'Malley dan Pierce tersebut karena model ini sesuai dengan kebutuhan peneliti dalam mengambil data di lapangan. Adapun alasan peneliti memilih model O’Malley dan Pierce sebagai model penelitian dan pengembangan ini adalah karena model ini pada dasarnya dirancang untuk guru sebagai desain atau model dalam mengembangkan instrumen asesmen dalam pembelajaran. Selain itu, tahapan pada model ini mengarahkan peneliti untuk melakukan studi pendahuluan terlebih dahulu mengenai instrumen asesmen yang ada, serta melibatkan subjek ahli untuk menguji tingkat validitas dan realibilitas produk yang dikembangkan.

Desain uji coba produk instrumen asesmen dilakukan dengan dua tahap, yakni (1) desain uji coba ahli, dan (2) desain uji kelompok kecil. Pertama, desain uji coba ahli melibatkan subjek uji ahli asesmen, subjek uji ahli pembelajaran bahasa Indonesia, dan praktisi (guru). Uji coba ahli asesmen diujikan kepada Dr. Imam Agus Basuki, M.Pd selaku dosen Pascasarjana Universitas Negeri Malang. Uji coba ahli pembelajaran bahasa Indonesia diujikan kepada Prof. Dr. Imam Suyitno, M.Pd selaku dosen Pascasarjana Universitas Negeri Malang. Dan uji praktisi dilakukan kepada Yantri Indayasri, M.Pd selaku guru mata pelajaran kelas VIII di SMP. Kedua, desain uji kelompok kecil melibatkan siswa kelas VIII SMP Negeri 21 Malang. Uji coba produk dilakukan untuk mengukur tingkat validitas, realibilitas, kepraktisan produk buku instrumen asesmen yang telah dihasilkan.

Data dari hasil uji pada penelitian dan pengembangan ini diuraikan menjadi dua bagian, yakni data kualitatif dan kuantitatif. Data kualitatif diperoleh berdasarkan catatan berupa kritik, saran, maupun masukan yang diberikan ahli atau praktisi (guru) pada saat melakukan uji validasi baik secara lisan maupun tertulis. Data kuantitatif pada penelitian ini berupa skor yang diperoleh dari hasil uji angket kepada kelompok ahli dan praktisi, serta skor hasil siswa mengerjakan produk instrumen asesmen.

Teknik analisis data yang digunakan pada penelitian dan pengembangan ini terdiri atas dua, yakni teknik analisis data kualitatif dan data kuantitatif. Teknik analisis data kualitatif dilakukan untuk menganalisis data verbal berupa hasil wawancara, kritik, saran, dan komentar dari subjek uji ahli pada produk instrumen asesmen yang dikembangkan. Teknik analisis data kuantitatif dilakukan untuk menganalisis data nominal bentuk skor angka penilaian ahli berdasarkan angket penilaian ketika uji produk. Selain itu, data kuantitatif juga diperoleh berdasarkan hasil uji produk pada siswa kelas VIII. Kedua data tersebut dijadikan sebagai pertimbangan dalam menyempurnakan produk instrumen asesmen sebelum diimplementasikan kepada siswa dalam pembelajaran.

\section{HASIL}

Penelitian ini memiliki tujuan pokok untuk menghasilkn produk berbentuk buku instrumen asessmen yang memiliki tingkat validitas, realibilitas, dan kepraktisan yang baik. Pada bagian ini dipaparkan mengenai tiga hal, yaitu (1) deskripsi produk, (2) hasil uji produk instrumen asesmen, dan (3) revisi produk instrumen asesmen. Ketiga hal tersebut diuraikan sebagai berikut.

\section{Deskripsi Produk}

Penelitian dan pengembangan ini menghasilkan produk berupa instrumen asesmen berpikir kritis dalam membaca teks eksposisi yang dilengkapi buku panduan untuk guru. Buku Instrumen Asesmen Berpikir Kritis dalam Membaca Teks Eksposisi yang dikembangkan ini dirancang untuk digunakan siswa SMP kelas VIII. Buku instrumen asesmen ini terbagi atas tiga unit, yakni unit I yang terdiri dari sepuluh soal objektif dan lima soal uraian, unit II yang terdiri dari tiga belas soal uraian, dan unit III terdiri dari 14 soal uraian. Pada unit I, butir soal disusun berdasarkan teks bacaan eksposisi yang berjudul Membentuk Karakter lewat Permainan Tradisional, unit II teks eksposisi yang berjudul Terlalu Banyak Minum Air Putih Berbahaya?, dan unit III teks bacaan eksposisi yang berjudul Media Sosial dinilai Jadi Sarang Penyebaran Berita Hoaks?. Instrumen soal yang dikembangkan mengacu pada aspek kompetensi berpikir kritis (Facione \& Santa, 1990) yang terdiri dari kompetensi interpretasi, analisis, evaluasi, inferensi, eksplanasi, dan regulasi diri. Buku Panduan Instrumen Asesmen untuk guru hanya digunakan oleh guru untuk melakukan penerapan dan penyekoran hasil pekerjaan siswa. Buku panduan guru ini terdiri atas lima bagian, meliputi pendahuluan, bentuk instrumen asesmen, taksonomi berpikir kritis, petunjuk penggunaan instrumen asesmen, dan rubrik penilaian berpikir kritis dalam membaca teks eksposisi. 


\section{Hasil Uji Produk Instrumen Asesmen}

Produk yang telah dihasilkan pada penelitian dan pengembangan ini dilakukan dua tahap uji coba, yaitu uji kelompok ahli dan uji praktisi. Uji kelompok ahli melibatkan subjek ahli asesmen, dan ahli pembelajaran bahasa Indonesia, sedangkan uji praktisi melibatkan guru dan siswa SMP kelas VIII. Uji coba produk dilakukan untuk mengukur tingkat kelayakan dari segi validitas isi, validitas konstruk, realibilitas, kepraktisan, dan kemenarikan. Data perolehan berdasarkan hasil uji coba tersebut dipaparkan sebagai berikut.

\section{Analisis Data Hasil Uji Coba Ahli Asesmen}

Hasil uji dari ahli asesmen pada buku instrumen asesmen untuk siswa ini meliputi aspek (1) validitas isi, (2) validitas konstruk, (3) kepraktisan, dan (4) kemenarikan. Aspek validitas isi mendapatkan persentase 93,75\% dengan kualifikasi sangat layak. Aspek validitas konstruk mendapatkan persentase 81,25\% dengan kualifikasi layak. Aspek kepraktisan mendapatkan persentase 83,33\% dengan kualifikasi layak. Aspek kemenarikan mendapatkan persentase 75\% dengan kualifikasi layak. Dari data tersebut, dapat dikatakan bahwa produk buku instrumen asesmen untuk siswa memiliki kualifikasi layak untuk digunakan.

Selain memvalidasi buku instrumen asesmen, subjek ahli asesmen juga melakukan validasi terhadap buku panduan untuk guru. Aspek yang divalidasi pada buku panduan untuk guru, meliputi aspek (1) sasaran panduan asesmen mendapatkan persentase $85 \%$, (2) isi buku panduan mendapatkan persentase 85,71, (3) keterbacaan mendapatkan persentase 85\%, dan (4) kepraktisan mendapatkan persentase $87,5 \%$. Berdasarkan data tersebut, maka buku panduan untuk guru ini memiliki kategori sangat layak diimplementasikan.

Data verbal berupa catatan yang merupakan masukan atau saran dari ahli asesmen diperoleh sebanyak enam, yaitu (1) perhatikan penggunaan ejaan, (2) struktur kalimat harus benar, (3) penggunaan kalimat harus logis, (4) soal membaca hanya dapat dijawab kalau membaca, (5) perintah soal terletak di atas, dan (6) pilihan jawaban harus homogen pada soal objektif.

\section{Analisis Hasil Uji Coba Ahli Pembelajaran Bahasa Indonesia}

Hasil uji dari ahli pembelajaran bahasa Indonesia pada buku instrumen asesmen untuk siswa ini meliputi aspek (1) vadilitas isi, (2) valliditas konstruk, (3) kepraktisan, dan (4) kemenarikan. Aspek validitas isi mendapatkan tingkat persentase 93,75\% dengan kualifikasi sangat layak. Aspek validitas konstruk mendapatkan persentase $85 \%$ berarti tergolong memiliki kualifikasi layak. Aspek kepraktisan mendapatkan persentase 83,33\% dengan kualifikasi layak. Aspek kemenarikan mendapatkan persentase $75 \%$ dengan kualifikasi layak. Dari data tersebut, dapat dikatakan bahwa produk buku instrumen asesmen berpikir kritis dalam membaca teks eksposisi untuk siswa memiliki kualifikasi layak untuk diimplementasikan.

Terdapat empat aspek yang divalidasi ahli pembelajaran bahasa Indonesia pada buku panduan guru, di antaranya (1) sasaran panduan asesmen mendapatkan persentase 90\%, (2) isi buku panduan mendapatkan persentase 85,71, (3) keterbacaan memeroleh persentase $87,5 \%$, dan (4) kepraktisan mencapai persentase $87,5 \%$. Berdasarkan data tersebut, maka buku panduan untuk guru ini memiliki kategori sangat layak diimplementasikan.

\section{Analisis Uji Praktisi (Guru Bahasa Indonesia)}

Produk yang diujikan kepada guru adalah buku panduan guru. Hasil uji validasi yang dilakukan kepada guru bahasa Indonesia meliputi aspek (1) muatan isi buku yang dikembangkan, (2) penggunaan kebahasaaan, dan (3) keterterapan desain tampilan. Aspek muatan isi buku yang dikembangkan memeroleh persentase rata-rata 81,25\% dengan kualifikasi layak dan dapat diimplementasikan. Aspek penggunaan kebahasaan mendapatkan persentase rata-rata 75\% dengan kualifikasi layak dan dapat diimplimentasikan. Aspek keterterapan desain tampilan mendapatkan persentase rata-rata 85\% dengan kualifikasi sangat layak serta dapat untuk diimplementasikan. Kritik dan saran dari guru adalah soal yang dikembangkan terlalu banyak, sehingga siswa cenderung bosan dalam mengerjakannya.

\section{Analisis Hasil Uji Pada Siswa}

Hasil uji coba produk dilakukan pada siswa SMP kelas VIII. Berdasarkan hasil uji produk pada siswa, diperoleh data bahwa buku instrumen asesmen berpikir kritis dalam membaca teks eksposisi pada unit 1 memeroleh rata-rata persentase $80,2 \%$, unit II mendapatkan skor rata-rata 79,4\%, dan unit 3 memeroleh persentase 78,6\%. Data tersebut menunjukkan bahwa ketiga unit tersebut tergolong layak dan dapat diimplementasikan. Data mengenai hasil uji produk lebih jelasnya dapat dilihat pada tabel 1 .

\section{Analisis Hasil Uji Realibilitas}

Data hasil uji reliabilitas merupakan representasi dari kevalidan rubrik penyekoran pada buku panduan guru yang telah dikembangkan. Uji reliabilitas pada penelitian ini menggunakan uji reliabilitas inter-rater yaitu dengan membandingkan skor hasil penilaian dari korektor I dan II. Hasil yang diperoleh berdasarkan uji reliabilitas tersebut menunjukkan bahwasanya instrumen asesmen yang dihasilkan telah tergolong reliabel berdasarkan skor koefisien Cronbach's Alpha. Hal itu dibuktikan dari perolehan nilai hitung lebih besar daripada nilai koefisien korelasi Cronbach's Alpha minimum yang ditentukan. Uji reliabilitas pada instrumen asesmen unit I memeroleh skor perolehan koefisien $(r) 0,980$. Uji reliabilitas pada instrumen 
asesmen unit II memeroleh skor koefisien $(r)$ 0,977. Uji reliabilitas instrumen asesmen unit III memeroleh skor koefisien $(r)$ 0,980 . Berdasarkan perolehan nilai koefisien $(r)$ tersebut, dapat dikategorikan bahwa instrumen asesmen yang dihasilkan telah tergolong reliabel, karena skor perolehan lebih tinggi dari $0,6(>0,6)$. Data tersebut menjelaskan bahwa ada korelasi yang signifikan antara skor yang diberikan oleh kedua korektor. Hasil uji reliabilitas berdasarkan SPSS tersebut dapat dilihat pada tabel 2.

Tabel 1. Data Hasil Uji Produk Instrumen Asesmen

\begin{tabular}{|c|c|c|c|c|c|}
\hline No & Subjek Uji Coba & Buku Instrumen Asesmen Siswa & Skor (\%) & Buku Panduan Guru & Skor $(\%)$ \\
\hline \multirow[t]{4}{*}{1} & Ahli Asesmen & Validitas isi & $93,75 \%$ & Sasaran panduan asesmen & $85 \%$ \\
\hline & & Validitas konstruk & $81,25 \%$ & Isi panduan & $85,71 \%$ \\
\hline & & Kepraktisan & $83,33 \%$ & Keterbacaan & $85 \%$ \\
\hline & & Kemenarikan & $75 \%$ & Kepraktisan & $87,5 \%$ \\
\hline \multirow[t]{4}{*}{2} & Ahli Pembelajaran Bahasa Indonesia & Validitas isi & $93.75 \%$ & Sasaran panduan asesmen & $90 \%$ \\
\hline & & Validitas konstruk & $85 \%$ & Isi panduan & $85,71 \%$ \\
\hline & & Kepraktisan & $83,33 \%$ & Keterbacaan & $87,5 \%$ \\
\hline & & Kemenarikan & $75 \%$ & Kepraktisan & $87,5 \%$ \\
\hline \multirow[t]{3}{*}{3} & Guru Bahasa Indonesia & & & Muatan isi buku & $81,25 \%$ \\
\hline & & & & Penggunaan kebahasaan & $75 \%$ \\
\hline & & & & $\begin{array}{l}\text { Keterterapan desain } \\
\text { tampilan }\end{array}$ & $85 \%$ \\
\hline \multirow[t]{3}{*}{4} & Siswa & Unit 1 & $80,2 \%$ & & \\
\hline & & Unit 2 & $79,4 \%$ & & \\
\hline & & Unit 3 & $78,6 \%$ & & \\
\hline
\end{tabular}

Tabel 2. Hasil Perolehan Uji Reliabilitas dengan SPSS

\begin{tabular}{cccc}
\hline No & Instrumen Asesmen & Cronbach's Alpha & Number of Item \\
\hline 1 & Unit 1 & .980 & 2 \\
2 & Unit 2 & .977 & 2 \\
3 & Unit 3 & .980 & 2 \\
\hline
\end{tabular}

\section{Revisi Produk Instrumen Asesmen}

Revisi produk dilakukan untuk menyempurnakan produk yang telah dikembangkan sehingga layak untuk diimplementasikan sebagai alat penilaian dalam pembelajaran. Berdasarkan hasil validasi yang dilakukan kepada validator ahli (asesmen dan ahli pembelajaran), diperoleh data verbal berupa komentar, masukan, dan saran sebagai pertimbangan untuk memperbaiki produk instrumen asesmen beserta buku panduan. Pertama, revisi berdasarkan aspek validitas. Hal yang dilakukan perbaikan pada bagian ini adalah (1) mengganti alternatif jawaban pada soal objektif yang tidak homogen, (2) mengubah tata letak redaksi soal, (3) mengubah pilihan jawaban soal objektif, (4) mencermati/merevisi perintah soal, dan (5) mencermati penggunaan struktur kalimat. Kedua, revisi berdasarkan aspek kepraktisan. Komponen yang diperbaiki pada bagian ini meliputi (1) mengubah/memperbaiki kalimat pada bagian informasi penting buku instrumen asesmen untuk siswa, (2) memperbaiki petunjuk pengerjaan instrumen asesmen, (3) memperjelas rambu jawaban pada buku panduan.

\section{PEMBAHASAN}

Hasil akhir dari penelitian dan pengembangan yang dilakukan adalah instrumen asesmen berpikir kritis dalam pembelajaran membaca teks eksposisi untuk siswa kelas VIII SMP. Buku instrumen asesmen yang dihasilkan untuk siswa disertai dengan buku panduan untuk guru. Buku panduan tersebut disusun supaya memudahkan guru dalam melaksanakan penilaian dengan menggunakan buku instrumen yang telah dikembangkan dan memudahkan guru dalam melakukan penyekoran terhadap hasil belajar peserta didik.

Instrumen asesmen ini dirancang dengan menyesuaikan kebutuhan literasi siswa khususnya kelas VIII SMP. Instrumen ini merupakan perangkat penilaian pendukung bahan ajar yang digunakan di sekolah. Artinya, instrumen asesmen ini hanya dapat digunakan untuk penilaian atau evaluasi pada materi teks eksposisi. Instrumen asesmen yang dikembangkan ini dikonstruk dari KD 3.5 mengidentifikasi informasi teks eksposisi berupa artikel ilmiah populer dari koran/majalah yang didengar dan dibaca dan kompetensi dasar 4.5 menyimpulkan isi teks eksposisi/artikel ilmiah populer dari koran dan majalah yang didengar dan dibaca. Instrumen asesmen siswa ini disusun berdasarkan konsep kompetensi berpikir kritis yang dikemukakan Facione. Taksonomi berpikir kritis Facione terbagi atas enam aspek kompetensi, yaitu (1) menginterpretasi, (2) menganalisis, (3) mengevaluasi, (4) menginferensi, (5) mengeksplanasi, dan (6) regulasi diri. Dengan demikian, butir soal yang dikembangkan disusun berdasarkan keenam tingkatan berpikir kritis tersebut. 
Produk Instrumen Asesmen Berpikir Kritis dalam Pembelajaran Membaca Teks Eksposisi dirancang untuk siswa SMP kelas VIII ini terdiri atas tiga unit, yakni (1) unit I tes pilihan ganda, (2) unit II tes uraian, dan (3) unit III tes uraian. Pada unit I, soal yang dikembangkan terbagi atas soal objektif dan soal uraian. Jumlah soal pada unit ini adalah 10 soal objektif dan lima soal uraian. Pada unit II, soal yang dikembangkan terdiri atas 13 soal uraian. Pada unit III, soal yang dikembangkan terdiri atas 14 soal uraian. Butir soal tersebut disusun berdasarkan kisi-kisi dan aspek tingkatan kemampuan berpikir kritis.

Pada produk instrumen asesmen berpikir kritis dalam membaca teks eksposisi ini dilakukan revisi sebanyak dua tahapan, yaitu (1) revisi berdasarkan masukan dan saran dari ahli asesmen dan (2) masukan dan saran dari ahli pembelajaran bahasa Indonesia. Berdasarkan hal tersebut, revisi dilakukan pada butir soal tes, pilihan jawaban soal objektif, keterbacaan redaksi butir soal, dan petunjuk pengerjaan soal.

\section{SIMPULAN}

Produk konkret yang diperoleh pada penelitian dan pengembangan ini adalah buku instrumen asesmen yang digunakan untuk siswa beserta buku panduan yang dapat digunakan guru dalam mengimplementasikan buku instrumen siswa. Desain uji coba produk yang dihasilkan dilakukan melalui dua cara, yakni (1) uji validasi dan (2) uji lapangan/produk. Setelah tahap uji coba dilakukan, selanjutnya dilakukan uji reliabilitas produk untuk mengukur tingkat keajegan produk yang telah dihasilkan. Paparan mengenai hasil uji tersebut diuraikan sebagai berikut.

Hasil uji validasi produk. Tahap validasi dilakukan dengan melibatkan subjek validator ahli asesmen dan validator ahli pembelajaran. Berdasarkan uji validasi yang dilakukan, diperoleh data bahwa instrumen yang dihasilkan tergolong layak untuk diimplementasikan. Hal itu terbukti dari perolehan hasil validasi dari validator asesmen untuk buku instrumen asesmen siswa mendapatkan persentase rerata $83,33 \%$ dan $85,71 \%$ untuk buku panduan guru. Hasil validasi dari validator ahli pembelajaran pada buku instrumen asesmen untuk siswa mendapatkan persentase $85,93 \%$ dan $85,71 \%$ untuk buku panduan guru. Hasil uji coba produk pada siswa. Hasil uji praktisi (guru bahasa Indonesia) pada buku panduan memeroleh persentase 80,41\%. Hasil uji lapangan/uji produk pada siswa mendapatkan persentase rata-rata 79,4\%. Berdasarkan data tersebut dapat dikategorikan bahwa produk yang telah dikembangkan memiliki kualifikasi layak dan dapat untuk diimplementasikan.

Selain uji validasi produk, uji reliabilitas juga dilakukan pada produk untuk mengukur keajegan rubrik atau ramburambu penyekoran pada buku panduan untuk guru. Berdasarkan hasil uji reliabilitas, instrumen unit I memeroleh skor koefisien korelasi 0,980, instrumen unit I memeroleh skor koefisien korelasi 0,977, dan instrumen unit III memeroleh nilai koefisien 0,980. Dari nilai koefisien yang diperoleh tersebut, dapat dibuat kesimpulan bahwasanya produk instrumen asesmen berpikir kritis dalam pembelajaran membaca tersebut telah memenuhi kriteria reliabel.

Saran pada penelitian dan pengembangan ini terbagi atas tiga bagian, yaitu (1) saran pemanfaatan produk, (2) saran diseminasi, dan (3) saran pengembangan produk lebih lanjut. Saran yang dihasilkan peneliti diuraikan sebagai berikut. Pertama, saran pemanfaatan produk instrumen asesmen diarahkan kepada (1) guru bahasa Indonesia, (2) siswa, dan (3) peneliti selanjutnya. Guru bahasa Indonesia yang mengajar kelas VIII dapat memanfaatkan produk instrumen yang telah peneliti kembangkan sebagai alat penilaian untuk mengukur kompetensi berpikir kritis siswanya terkhusus materi teks eksposisi. Siswa dapat memanfaatkan produk ini sebagai bahan latihan dalam mengembangkan kompetensi berpikir kritis, memecahkan masalah, sehingga dengan demikian siswa akan terlatih dalam berpikir secara kritis, kreatif, inovatif dan siap menghadapi tantangan global. Peneliti selanjutnya dapat memanfaatkan produk instrumen ini sebagai panduan, acuan, maupun rujukan dalam merancang instrumen penilaian yang lebih kreatif dan inovatif yang berkaitan dengan pengembangan kompetensi berpikir kritis.

Kedua, saran diseminasi yang diarahkan peneliti melalui (1) publikasi jurnal ilmiah guna memudahkan akademisi, guru dalam mengakses dan membaca bahkan merujuknya sekalipun, (2) forum MGMP guna meninjau kelebihan dan kekurangan produk yang dihasilkan, dan (3) penyebarluasan produk di sekolah guna membantu guru dalam memberikan referensi sekaligus rujukan penilaian khususnya pada materi pelajaran teks eksposisi.

Ketiga, saran pemanfaatan produk lebih lanjut. Produk ini dapat dijadikan sebagai bahan latihan untuk mengukur kompetensi berpikir kritis siswa melalui teks eksposisi. Meskipun demikian, peneliti menyadari bahwa produk yang dihasilkan masih memiliki kekurangan sehingga peneliti selanjutnya dapat menggunakan produk ini sebagai landasan, acuan, model dalam mengonstruk instrumen asesmen yang lebih kreatif dan inovatif sesuai dengan perkembangan zaman.

\section{DAFTAR RUJUKAN}

Abidin, Y. (2016). Revitalisasi Penilaian Pembelajaran dalam Konteks Pendidikan Multiliterasi Abad Ke-21. Bandung: PT Refika Aditama.

Aghajani, M., \& Gholamrezapour, E. (2019). Critical Thinking Skills, Critical Reading and Foreign Language Reading Anxiety in Iran Context. International Journal of Instruction, 12(4), 219-238. https://doi.org/10.29333/iji.2019.12414a

Batur, Z., Başar, M., \& Nilüfer Süzen, H. (2019). Critical Visual Reading Skills of Students. International Journal of Education and Literacy Studies, 7(3), 38. https://doi.org/10.7575/aiac.ijels.v.7n.3p.38

Bećirović, S., Hodžić, F., \& Brdarević-Čelj, A. (2019). Critical Thinking Development in the Milieu of High School Education. European Journal of Contemporary Education, 8(3). https://doi.org/10.13187/ejced.2019.3.469

Black, P., \& Wiliam, D. (1998). Assessment and Classroom Learning. Assessment in Education: Principles, Policy \& Practice, 5(1), 7-74. https://doi.org/10.1080/0969595980050102 
Cahyanto, Z. D., Basuki, I. A., \& Martutik. (2016). Pengembangan Instrumen Asesmen Membaca Kritis untuk Siswa SMA/SMK Kelas X dan XI. Jurnal Pendidikan: Teori, Penelitian, dan Pengembangan, 1(5), 780-784.

Chusnia, S., Sa'dijah, C., \& Harsiati, T. (2017). Penerapan Instrumen Asesmen Autentik Matematika Aspek Kognitif dan Keterampilan Bagi Siswa KelaS IV SD. Jurnal Pendidikan: Teori, Penelitian, dan Pengembangan, 2(10), 1437-1442.

Dharmawati., Rahayu, S., \& Mahanal, S. (2016). Pengembangan Instrumen Asesmen Berpikir Kritis untuk Siswa SMP Kelas VII pada Materi Interaksi Makhluk Hidup dengan Lingkungan. Jurnal Pendidikan: Teori, Penelitian, dan Pengembangan, 1(8), 1598-1606.

Doble, C., Matayoshi, J., Cosyn, E., Uzun, H., \& Karami, A. (2019). A Data-Based Simulation Study of Reliability for an Adaptive Assessment Based on Knowledge Space Theory. International Journal of Artificial Intelligence in Education, 29(2), 258-282. https://doi.org/10.1007/s40593-019-00176-0

Ekawatiningsih, P. (2015). Pengembangan Instrumen Penilaian Berbasis Kompetensi untuk Meningkatkan Kualitas Pembelajaran Produktif di SMK. INVOTEC, XI(1), 91-112.

Facione, P. A., \& Santa, C. U. (1990). Critical Thinking: A Statement of Expert Consensus for Purposes of Educational Assessment and Instruction. Research Findings and Recommendations: Prepared for the Committee on Pre-College Philosophy of the American Philosophical Association. Retrieved from Http://Www.Eric.Ed.Gov/ERICWebPortal/RecordDetail?Accno=ED315423, 423(c), 0-19.

Gotoh, Y. (2016). Development Of Critical Thinking With Metacognitive Regulation. 13th International Conference on Cognition and Exploratory Learning in Digital Age (CELDA 2016), 4.

Indradi, A. (2016). Pengembangan Bahan Ajar Bahasa Indonesia untuk Berpikir Kritis. Universitas Negeri Malang. (Malang).

Kasmadi., Harsiati, T., \& Nurhadi. (2016). Pengembangan Perangkat Asesmen Autentik Keterampilan Menulis Kelas VII dalam Implementasi Kurikulum 2013. Jurnal Pendidikan Humaniora, 4(2), 106-114.

Maltepe, S. (2016). An Analysis of the Critical Reading Levels of Pre-service Turkish and Literature Teachers. Eurasian Journal of Educational Research, 16(63), 168-184. https://doi.org/10.14689/ejer.2016.63.10

Mueller, J. (2015). The Authentic Toolbox: Enchancing Student Learning Trough Online Faculty Development. North Central College, 1(1), 1-7.

Nabilah, A., Damaianti, V. S., \& Agustin, M. (2018). Pengembangan Instrumen untuk Mengukur Kemampuan Persepsi Visual dan Kesadaran Linguistik Siswa Sekolah Dasar. Profesi Pendidikan Dasar, 1(1), 90. https://doi.org/10.23917/ppd.v1i1.6110

O’Malley, J. M., \& Pierce, L. V. (1996). Authentic Assessment for English Language Learners. USA: Addison-Wesley Publishing.

Paul, R., \& Elder, L. (2002). Critical thinking: Tools for taking charge of your professional and personal life. Upper Saddle River, NJ: Financial Times/Prentice Hall.

Sari, T. P., Dawud, \& Andajani, K. (2019). Hubungan Kemampuan Berpikir Kritis dengan Kemampuan Menulis Teks Editorial Siswa Kelas XII. Jurnal Pendidikan: Teori, Penelitian, dan Pengembangan, 4(1), 51-55.

Sudjana, N. (2017). Penilaian Hasil Proses Belajar Mengajar (21 ed.). Bandung: PT Remaja Rosdakarya Offset.

Tosuncuoglu, I. (2018a). Importance of Assessment in ELT. Journal of Education and Training Studies, 6(9), 163. https://doi.org/10.11114/jets.v6i9.3443

Tosuncuoglu, I. (2018b). Place of Critical Thinking in EFL. International Journal of Higher Education, 7(4), 26. https://doi.org/10.5430/ijhe.v7n4p26

Wahyuni, S., \& Ibrahim, Abd. S. (2014). Asesmen Pembelajaran Bahasa. Bandung: PT Refika Aditama.

Wardani, H. (2017). Pengembangan Instrumen Asesmen Presentasi Ilmiah di SMA. Muaddib: Studi Kependidikan dan Keislaman, 6(2), 127. https://doi.org/10.24269/muaddib.v6n2.2016.127-146

Wijayanti, E., \& Mundilarto, M. (2015). Pengembangan Instrumen Asesmen Diri dan Teman Sejawat Kompetensi Bidang Studi pada Mahasiswa. Jurnal Penelitian dan Evaluasi Pendidikan, 19(2), 129-144. https://doi.org/10.21831/pep.v19i2.5572

Xu, Y., \& Liu, Y. (2009). Teacher Assessment Knowledge and Practice: A Narrative Inquiry of a Chinese College EFL Teacher's Experience. TESOL Quarterly, 43(3), 492-513. https://doi.org/10.1002/j.1545-7249.2009.tb00246.x

Yeo, M., \& Boman, J. (2019). Disciplinary approaches to assessment. Journal of Further and Higher Education, 43(4), 482493. https://doi.org/10.1080/0309877X.2017.1367371

Zainal, A., Priyatni, E. T., \& Widiati, N. (2018). Instrumen Asesmen Berbasis Higher Order Thinking Skills dengan Memanfaatkan Kumpulan Cerpen Filosofi Kopi untuk Kelas X. Jurnal Pendidikan: Teori, Penelitian, dan Pengembangan, 3(12), 1561-1571.

Zhang, L., \& Kim, S. (2018). Critical Thinking Cultivation in Chinese College English Classes. English Language Teaching, $11(8), 159$. https://doi.org/10.5539/elt.v11n8p159 